Journal of Educational Research in Developing Areas (JEREDA

Vol. 2. Issue 2, Pp. 153-163, 2021

http://www.jeredajournal.com

E-mail: info@jeredajournal.com

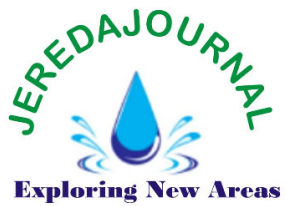

Research Article DOI: https://doi.org/10.47434/JEREDA.

eISSN: $2735-9107$

\title{
RELATIONSHIP OF LEARNING ENVIRONMENT TO LEARNERS' ATTENDANCE IN PUBLIC PRIMARY SCHOOLS IN KWARA STATE, NIGERIA
}

\author{
${ }^{1}$ Folorunsho Muhammed Shuaib, ${ }^{2}$ Abayomi Ajayi Rilwan \\ ${ }^{3}$ Olayiwola Oladimeji
}

${ }^{1}$ Department of Educational Foundation and Curriculum, Ahmadu Bello University, Zaria'

${ }^{2}$ Dept of Vocational Education, Modibbo Adama University, Yola

${ }^{3}$ Department of Educational Management, University of Ilorin

Email: 2abayor4u@gmail.com; ${ }^{3}$ layonic2015@gmail.com

Corresponding Author ${ }^{1}$ shuaibfm3@gmail.com

(i) https://orcid.org/0000-0002-4265-9466

Received:25 $5^{\text {th }}$ May, 2021; Revised:31 ${ }^{\text {st }}$ May, 2021; Accepted:08 ${ }^{\text {th }}$ August, 2021

\begin{abstract}
Introduction: Primary schools system is a place where pupils receive knowledge between the ages of 6 to 11.The study examined the relationship between learning environment and pupils' attendance in public primary schools in Kwara State.

Purpose: The study examined the impact of well-ventilated classroom, furnished computer/laboratory and good furniture facilities on pupils' attendance in primary schools in Kwara State.
\end{abstract}

Design: The target population of the study was 2,400 teachers of public primary schools in the State; the sample was 145 teachers of selected primary schools in each of the senatorial district in Kwara State using simple random sampling technique. The instruments used for the study were researchers' designed questionnaires titled "Learning Environment Questionnaire (LEQ)" and "Pupils' Attendance Questionnaire (PAQ)". The questionnaire was administered on selected teachers in the sampled public primary schools in Kwara State.The questionnaires were subjected to content validation by given to 2 experts from the field of education. The reliability coefficient of the instrument was found to be 0.75 and 0.62 using Cronbach Alpha statistics. Statistics of means and standard deviation were used to answer the research questions while Pearson Product Moments Correlation (PPMC) was adopted to test the hypotheses raised in the study using SPSS version 21.0 at 0.05 level of significance.

Results: The study revealed that a good learning environment has a positive impact on pupils' attendance in public primary schools in Kwara State.

Recommendations: Recommendation was made that Government through SUBEB to ensure more classrooms with wider space are provided for schools to accommodate more pupils and many others.

Keywords: Learning environment, pupils' attendance, public primary schools, physical facilities

\section{Cite paper as:}

Crossref Shuaib, F. M., Rilwan, A. A., Olayiwola, O. (2021). Relationship of Cited-by learning environment to learners' attendance in public primary schools in Kwara state, Nigeria. Journal of Educational Research in Developing Areas, 2 (2), 153-163. https://doi.org/10.47434/JEREDA/2.2.2021.153.

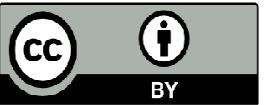

Copyright (c) 2021 The author(s) of this article retain(s) the copyright. 
Journal of Educational Research in Developing Areas (JEREDA

Vol. 2. Issue 2, Pp. 153-163, 2021

http://www.jeredajournal.com

E-mail: info@jeredajournal.com

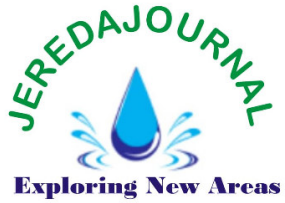

\section{PUBLIC INTEREST STATEMENT}

The study is important benefit to the following: Universal Basic Education Commission (UBEC), Kwara State Universal Basic Education Board (SUBEB), Local Government Education Authority (LGEA), Head of Schools at the basic level of education in the state and other educational researchers. It would be significant to the highlighted beneficiaries because of their importance to the provision of relevant facilities to improve the learning environment in primary schools in Kwara State. It will also guide them on the needs for allocation and provision of more funds to primary schools in the state to improve the learning environment in Kwara State.

\section{INTRODUCTION}

Education system in Nigeria is a 6-3-3-4 policy that comprised of six (6) years primary school education, three (3) years junior secondary school education, three (3) years senior secondary school education and four (4) years in higher education. Also, the 6 years primary and 3 years junior secondary school are categorized into Basic education (9-year period) in Nigeria. However, National Policy on Education (FGN, 2014: Section 4) identified primary education as education given in the institution for children between the age of 6 to 11 plus; with the primary goals of providing permanent literacy and numeracy and the ability to communicate effectively, to provide the child/ pupils with the basic tools for further educational advancement, including preparation of trades and crafts of the locality, to mould the child's character and develop sound attitude and morals and so on. These goals will therefore form the basis of implementation of primary education in all states in Nigeria as guided by the State Universal Basic Education Board (SUBEB) and other relevant agencies.

The school learning environment is referred to by many researchers to be physical compositions of the school environment, while others referred to the term as staff relations, leadership styles, morale, cooperation among the members (Oluremi, 2012). Moreover, learning environment is known as available space for the learners to interact with the things or people around them; this is not restricted to the classroom building alone butto other such as a library, a science laboratory or any other places where learning can take place. In another related concept, learning environment is defined as a diverse platform where Volume 2, Number 2 usersare engaged and interact with others to learn new skills, while learners can learn in an array of settings (Raccoon, 2018). School environment therefore consists of both physical and human facilities. The physical facilities comprise of the school administrative offices, staff room(s), generating set, car park, school field, pavilion, games court, fence, electricity, school bus/cars/ motorcycles, modern building, beautifulness of environment and location of the school. In addition to this, learning environment are counselling office, computer room/ equipment, music room, Head of Department's offices, chairs, tables, desk/ lockers, benches, laboratories, laboratory equipment/ facility, library, textbooks, chalks, air conditioner, and fan.

Also, learning environment is referred to as an educational approach, cultural context, or physical setting in which teaching and learning occurs. The term is commonly used as a more definite alternative to "open classroom", but it is typically referring to the context of educational philosophy or knowledge experienced by the student and may also encompass a variety of cultures -its presiding ethos and characteristics, how individual interact, governing structures and philosophy. Therefore, classroom environment is a very significant factor among others that affects students learning. In other words, students learn better when they perceive their learning environment to be encouraging and helpful. (Dorman et. al., 2006).

However, the human facilities of the school learning environment consist of the students or pupils, the academic and non-academic staff. Consequently, there is need to maintaina good and cordial relationship among the pupils, the 
Journal of Educational Research in Developing Areas (JEREDA

Vol. 2. Issue 2, Pp. 153-163, 2021

http://www.jeredajournal.com

E-mail: info@jeredajournal.com

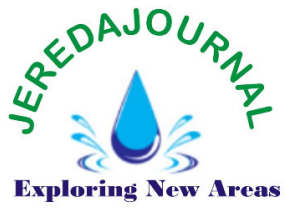

teaching staff and the non-teaching staff in the school environment to encourage pupils' attendance in the school. Also, in a situation where the school learning environment is not conducive and convenient for the pupils and the staff, the overall population of the human facility will be affected negatively and the goals of primary education system might not be fully achieved. The level of interaction with the students and how students interact with one another may be considered part of a learning environment and phases such as a "positive learning environment" are commonly used in dimensions of a school or class (Powell \& Driver, 2013).

Moreover, the level of pupils' attendance in the primary school system will be motivated by the availability of a well-composed, furnished and ventilated learning environment which eventually improve both the learning/ teaching process in the school system. Therefore, pupils' attendance referred to the rate at which pupils are willing to attend a school in a formal setting. Teddlie and Reynolds (2000) posited that school organization and climate are likely to have differential effects on students' perceptions of school life which in turn affect their engagement and participation. Consequently, the willingness of pupils to attend school based on the available good learning environment will help improve the pupil's performance in school and thereby improve the overall school learning outcome. The amount of enhanced learning environment, in conjunction with other determining variables, will influence and promote school attendance at the primary level of education.

The amount of enhanced learning environment, in conjunction with other determining variables, will influence and promote school attendance at the primary level of education. Therefore, learning environment is referred to the diverse physical location, context and cultures in which students/pupils learn in a wide variety of settings that may be outside the school location or outdoor environment. The term is often used as a more accurate or preferred alternative classroom which are more limited and

traditional connotations- a room with rows of desks and a chalkboard (Glossary of Educational Reform, 2013).

However, Terry (2021) identified the following as the characteristics of school learning environment: the students are free to ask more questions than teachers, ideas come from divergent sources, variety of learning models are available for use, learning habits are constantly modeled, there are constant and creative opportunities and growth, the students feel physically and emotionally safe, classroom structure provides multiple and varied opportunities for students to experience success. The teacher gets to know all his regular students and uses that knowledge to create a meaningful experience. Therefore, it is on this background that the study was carried out to examine the effects of learning environment on pupils' attendance in public primary schools in Kwara State, Nigeria.

\section{STATEMENT OF THE PROBLEM}

The enabling learning environment is very essential to pupils' attendance in primary school in Nigeria. Provision of relevant physical and human facilities at the primary level of education will motivate the pupils' attendance in class and thereby encourage pupils' level of performance in the school. However, many of these facilities that constitute the learning environment at the public primary schools in Kwara state are already dilapidated and not conducive for learning/ teaching process in some schools. Such dilapidated facilities include classrooms, toilet facilities, inadequate furniture facilities, broken tables and chairs for staff and so on. Related literature were reviewed on this study, such as Aiwuyo and Omoera (2019), their study was conducted on 'assessment of the learning environment of early childhood and development education in public schools in Esan West Local Government area of Edo State Nigerian'. Oluremi (2012) conducted the research on 'creating a friendly school learning environment for Nigerian children'. However, these facilities, if not 
Journal of Educational Research in Developing Areas (JEREDA

Vol. 2. Issue 2, Pp. 153-163, 2021

http://www.jeredajournal.com

E-mail: info@jeredajournal.com

adequately provided and conducive will affect the pupils' attendance in the primary schools and in view of this, the study was conducted in order to critically examine the relationship that exist between the learning environment and pupils' attendance in primary schools in Kwara State.

\section{PURPOSE OF THE STUDY}

The main objective of this study was to examine the relationship that exists between the learning environment and pupils' attendance in public primary schools in Kwara State, Nigeria.Other objectives of the study were to examine:

1. The impact of well ventilated/ furnished classroom on pupils' attendance in public primary schools in Kwara State.

2. The impact of well-furnished computer/ laboratory on pupils' attendance in public primary schools in Kwara State.

3. The impact of good furniture/ fittings facilities on pupils' attendance in public primary schools in Kwara State.

\section{RESEARCH QUESTIONS}

The following research questions were raised for the study:

1. What is the impact of a wellventilated classroom on pupils' attendance in public primary schools in Kwara State?

2. What is the impact of a well furnished computer/ laboratory on pupils' attendance in public primary schools in Kwara State?

3. What is the impact of good furniture/ fittings facility on pupils' attendance in public primary schools in Kwara State?

\section{HYPOTHESES}

1. There is no significant relationship between a well-ventilated classrooms and pupils' attendance in public primary schools in Kwara State.

2. There is no significant relationship between furnished computer/ laboratory and pupils' attendance

in public primary schools in Kwara State.

3. There is no significant relationship between good furniture/fittings facility and pupils' attendance in public primary schools in Kwara State?

\section{METHODOLOGY Research Design}

The study adopted a descriptive research survey of correlation type. This design was used because it describes the relationship that exists between the learning environment and pupils' attendance in public primary schools. The design also enables the researchers to provide answers to the research questions raised in the study.

\section{Population and Sample}

The population of the study comprised of all the 1,492 public primary schools in Kwara State with a target population of 2,400 teachers (Kwara State Ministry of Education, Science \& Technology, 2010). The population was stratified into three Senatorial districts, that is, Kwara Central, North and South. Simple random sampling technique adopted to pick two (2) local government areas from the three (3) senatorial districts in the Kwara state. While proportional sampling technique was used to select ten (10) primary schools from Kwara Central, five (5) primary schools each from both Kwara North and South senatorial districts of the state because of the population difference of the schools. A sample size of 145 respondents (teachers) was determined out of the 2,400 target population of teachers in the state using research advisors (2006).

The demographic data of the respondents on staff qualifications, position and experience in the sampled schools of the study in Kwara State are explained thus: The response of the samples/ respondents on staff qualification are as follows: NCE 13 represents 9\%; B.Ed. 43(29.7\%); M.Sc./M.Ed. $88(60.7 \%)$ and Ph.D. staff was1 representing $7 \%$ of the total respondents. Also, the responses on staff 
Journal of Educational Research in Developing Areas (JEREDA

Vol. 2. Issue 2, Pp. 153-163, 2021

http://www.jeredajournal.com

E-mail: info@jeredajournal.com

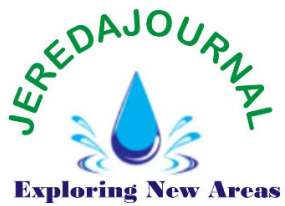

position were: 20 (13.8\%) for Headmasters/ Headmistresses, 67 $(46.2 \%)$ for HODs and $61(42.1 \%)$ for classroom teachers in all sampled schools administered. Consequently, the response on staff experience based on the administered schools were: $0-5$ years of experience was 25 representing $17.5 \%, 6-10$ years of experience was 69 which represents $47.6 \%, 11-15$ years of experience was 20 representing $13.5 \%$, 16-25 years of experience was 12 which represents $8.3 \%$ and 25 years of experience and above was 19 which represents about $13.1 \%$.

\section{Instruments for Data Collection}

The instruments used for the study for data collection were researchers' designed questionnaires tagged: 'Learning Environment Questionnaire (LEQ)' and 'Pupils' Attendance Questionnaire (PAQ)'. The questionnaire was administered to all the teaching staff of sampled public primary schools in Kwara State.The items of the two instruments were scaled as:Strongly Agree $(S A)=4$, Agree $(A)=3$, Disagree(D) $=2$, Strongly Disagree $(S D)=1$. The questionnaire was validated by experts in the educational administration and planning, all their corrections and observations made were taken into

consideration before the final production. The reliability coefficients of the instruments were found to be 0.75 and 0.62 respectively using Cronbach Alpha statistics.

\section{Procedure of Data Collection}

The researchers with support of a research assistants personally went to the sampled primary schools in the three senatorial districts of Kwara State for administering of the instruments raised and were retrieved back immediately.

\section{Method of Data Analysis}

Data collected were subjected to coding and analysis using Statistical Package for Social Science (SPSS) version 21.0. Inferential statistics of means and standard deviation were adopted to answer the research questions raised in the study with percentage frequency for demographic data collected. The Pearson Products Moment Correlation (PPMC) was used to test the formulated hypotheses at 0.05 level of significance.

\section{RESULTS}

Research Question 1: What is the impact of a well ventilated classroom on pupils' attendance in public primary schools in Kwara State?

Table 1: Responses on the impact of a well ventilated classroom on pupils' attendance in public primary schools in Kwara State.

\begin{tabular}{|c|c|c|c|c|}
\hline $\mathbf{S} / \mathbf{N}$ & Items & Mean & Std.Dev. & Impact \\
\hline 1. & $\begin{array}{l}\text { Availability of a well ventilated classroom in } \\
\text { primary school motivates pupils' attendance }\end{array}$ & 3.44 & .498 & Positive \\
\hline 2. & $\begin{array}{l}\text { A well structured classroom encourage pupils' } \\
\text { attendance in primary schools }\end{array}$ & 3.30 & .569 & Positive \\
\hline 3. & $\begin{array}{l}\text { A well serene environment in public primary } \\
\text { schools in Kwara state encourage pupils' } \\
\text { attendance in the system }\end{array}$ & 2.74 & 1.106 & Positive \\
\hline 4. & $\begin{array}{l}\text { A well structured classroom arrangement encour } \\
\text { pupils' attendance in public primary schools in } \\
\text { Kwara State }\end{array}$ & 3.58 & .779 & Positive \\
\hline 5. & $\begin{array}{l}\text { Provision of wide space classroom encourages } \\
\text { pupils' attendance inpublic primary schools in } \\
\text { Kwara State }\end{array}$ & 2.21 & .996 & Negative \\
\hline AVEF & RAGE MEAN SCORES & 3.05 & & \\
\hline
\end{tabular}

Minimum Mean Value: $\geq 2.50$ 
Journal of Educational Research in Developing Areas (JEREDA

Vol. 2. Issue 2, Pp. 153-163, 2021

http://www.jeredajournal.com

E-mail: info@jeredajournal.com

Table 1 shows the result of the responses on the impact of a well ventilated classroom on pupils' attendance in public primary schools in Kwara State. From the table, all the mean values were above the minimum mean value of 2.50 except item 5 which indicates that the provision of wide space classrooms encourages pupils' attendance in public primary schools in Kwara State with the mean value of 2.21 . However, since majority of the items are

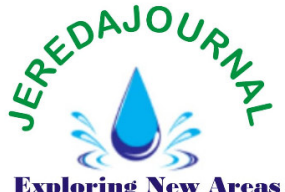

Exploring New Areas

Table 2: Responses on the impact of a well furnished computer/laboratory on pupils' attendance in public primary schools in Kwara State.

\begin{tabular}{|c|c|c|c|c|}
\hline $\mathbf{S} / \mathbf{N}$ & Items & Mean & Std. Dev. & Impact \\
\hline & $\begin{array}{l}\text { A well furnished computer studio encourages } \\
\text { pupils' attendance in public primary schools } \\
\text { in Kwara state }\end{array}$ & 3.30 & .884 & Positive \\
\hline 2. & $\begin{array}{l}\text { Good sitting arrangement in computer room } \\
\text { Encourages pupils' attendance in public } \\
\text { primary schools in Kwara State }\end{array}$ & 3.27 & .700 & Positive \\
\hline 3. & $\begin{array}{l}\text { A conducive computer laboratory system in } \\
\text { public primary schools in Kwara state motivates }\end{array}$ & & & \\
\hline & $\begin{array}{l}\text { pupils' attendance } \\
\text { Provision of adequate computer software } \\
\text { system in public primary schools in Kwara state } \\
\text { encourages pupils' attendance in the school }\end{array}$ & 3.66 & .570 & Positive \\
\hline & system. & 3.01 & .583 & Positive \\
\hline & $\begin{array}{l}\text { Installation and provision of adequate computer } \\
\text { System in the computer studio in public primary } \\
\text { schools in Kwara State encourages pupils' }\end{array}$ & & & \\
\hline & $\begin{array}{l}\text { attendance in the school } \\
\text { RAGE MEAN SCORES }\end{array}$ & $\begin{array}{l}3.48 \\
\mathbf{3 . 3 4}\end{array}$ & .746 & Positive \\
\hline
\end{tabular}

Minimum Mean Value: $\geq 2.50$

In table 2, the result of the responses on the impact of a well furnished computer/ laboratory on pupils' attendance in public primary schools in Kwara State was shown. The result shows that all the mean values of the items are above the mean value of 2.50 , which ranges from 3.01 to 3.66 . With the average mean score of 3.34 higher than the minimum mean value, the result above the minimum mean value and consequently the average mean scores was 3.05, it was therefore revealed that a well-ventilated classroom has a positive impact on pupils' attendance in public primary school in Kwara State.

Research Question 2: What is the impact of a well furnished computer/laboratory on pupils' attendance in public primary schools in Kwara State? 
Journal of Educational Research in Developing Areas (JEREDA

Vol. 2. Issue 2, Pp. 153-163, 2021

http://www.jeredajournal.com

E-mail: info@jeredajournal.com

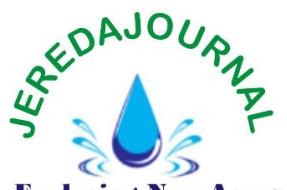

Table 3: Response on the impact of good furniture/fittings facility on pupils' attendance in public primary schools in Kwara State.

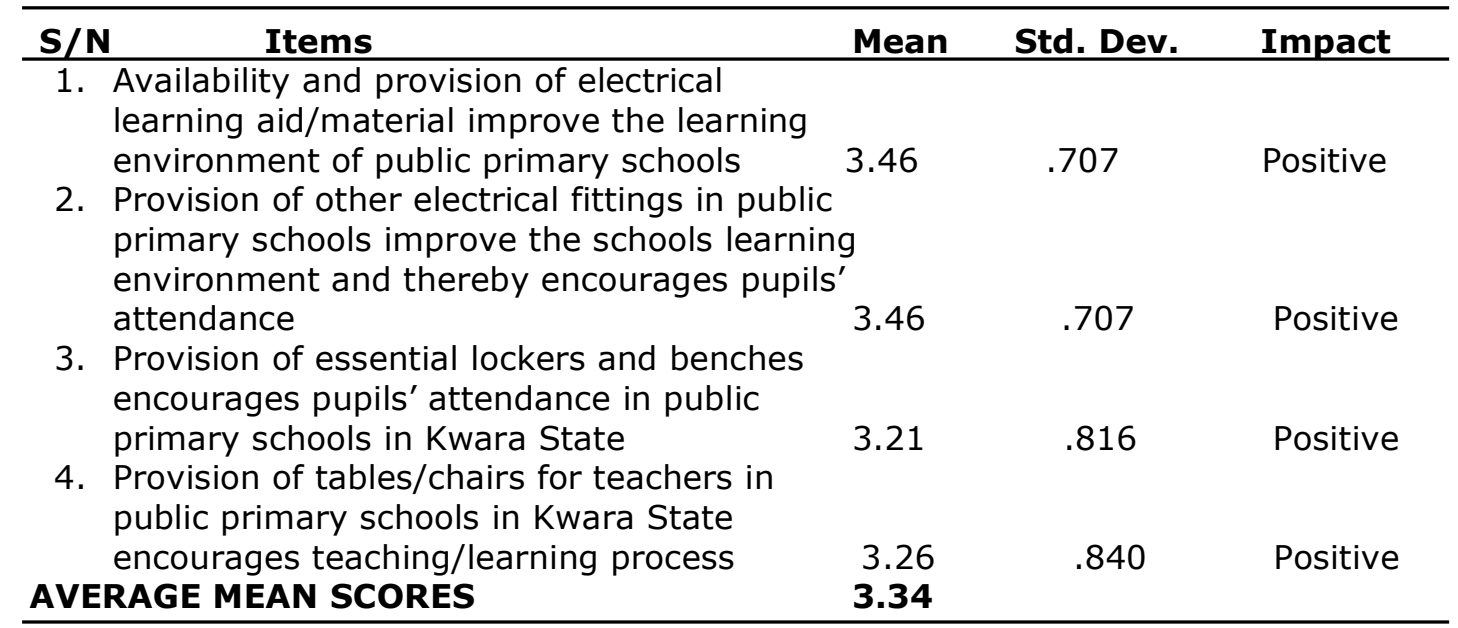

Minimum Mean Value: $\geq 2.50$

Table 3 shows the result of the responses on theimpact of good furniture/fittings facility on pupils' attendance in public primary schools in Kwara State. From the table, all the mean scores of the item of the constructs were above the minimum mean value of 2.50 , that is, it ranges between 3.21 and 3.46, showing that all the items have positive impact on pupils' attendance.

\section{Hypotheses}

Table 4: Summary of Pearson Correlation Results on Hypotheses Tested

\begin{tabular}{lllllll}
\hline Hypotheses & Relationship & $\mathbf{N}$ & Mean & t-Value & r. Value & Decision \\
\hline $\mathrm{Ho}_{1}$ & $\begin{array}{l}\text { Well Ventilated } \\
\text { Classroom Pupils' } \\
\Rightarrow \quad 145\end{array}$ & 13.51 & .000 & $.346^{* *}$ & Rejected \\
$\mathrm{Ho}_{2}$ & $\begin{array}{l}\text { Furnished computer } \\
\text { studio/ laboratory=> } \\
\text { pupils' attendance }\end{array}$ & 145.93 & .000 & $.790^{* *}$ & Rejected \\
$\mathrm{Ho}_{3}$ & $\begin{array}{l}\text { Good furniture/ } \\
\text { fittings facility => } \\
\text { pupils' attendance }\end{array}$ & 145 & 10.78 & .000 & $.655^{* *}$ & Rejected \\
\hline
\end{tabular}

**. Correlation is significant at the 0.05 level (2-tailed).

Hypothesis one stated that there is no significant relationship between a well-ventilated classroom and pupils' attendance in public primary schools in
Therefore, with the average mean score of 3.34, the result revealed that there is a positive impact of good furniture/fittings on pupils' attendance in public primary schools in Kwara State.
Kwara State. The result of the hypothesis as shown in table 4 row 1 , found out that the calculated $r$. value of .346 is greater than the $t$. value of .000 at 0.05 level of 
Journal of Educational Research in Developing Areas (JEREDA

Vol. 2. Issue 2, Pp. 153-163, 2021

http://www.jeredajournal.com

E-mail: info@jeredajournal.com

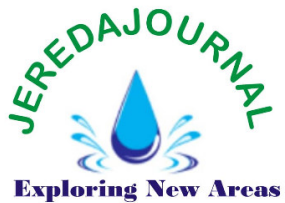

significance, hence, the hypothesis was rejected. Therefore, there is a significant relationship between a well ventilated classroom and pupils' attendance in public primary schools in Kwara State.

Hypothesis two stated that there is no significant relationship between furnished computer studio/ laboratory and pupils' attendance in public primary schools in Kwara State. From table 4 row 2 , the result showed the calculated $r$. value of .790 is greater than the $t$. value of .000 at a significant level of 0.05 , hence the hypothesis was rejected and there is a significant relationship between furnished computer studio/ laboratory and pupils' attendance in public primary schools in Kwara State.

Hypothesis three stated that there is no significant relationship between good furniture/fittings facilities and pupils' attendance in public primary schools in Kwara State. The result revealed that the calculated $r$. value of .655 is greater than the $t$. value .000 at a significant level of 0.05 and hence, the hypothesis was rejected as shown in table 5 row 3. Therefore, there was a significant relationship between good furniture/fittings facilities and pupils' attendance in public primary schools in Kwara State.

\section{Discussions}

Hypothesis one, which stated that there is no significant relationship between well ventilated classrooms and pupils' attendance in public primary schools in Kwara State was rejected. Hence, there is significant relationship between well ventilated classrooms and pupils' attendance in public primary schools in Kwara State. This implies that the availability of adequate classrooms and as well as been ventilated with necessary facilities have a positive effect on pupils' willingness to attend public primary schools in the state. It is expected that a classroom with more space and windows will allow natural fresh air and thereby motivate the pupils' attendance in the public primary schools in Kwara State. This result corroborated with the findings of Ezike (2018), that classroom atmosphere and students'

academic engagement predicted success in Senior Secondary School chemistry. Thus, unfavorable classroom atmosphere can discourage students and make them less eager to study, which in turn impacts their interest in classroom activities and, as a result, their attendance at school.

Hypothesis two, which stated there is no significant relationship between furnished computer/ laboratory and pupils' attendance in public primary schools in Kwara State was rejected. Therefore, there was significant relationship between furnished computer/ laboratory and pupils' attendance in public primary schools in Kwara State. A furnished computer room with relevant software packages and well equipped laboratory in public primary schools in Kwara State will motivate pupils to attend schools. This finding was supported by Otchere et. al. (2019) with their study conducted on examining the relationship between school facilities and the learning environment: A case study of Oda Senior High School. In this study, it was found that there was a significant relationship between school facilities and academic achievement among high school students in Oda Senior High School (SHS). The study therefore classified School facilities into three (3) namely: visual, audio and audio - visual or multi-sensory materials. In observing the school facilities present in Oda SHS, the researchers came out with an outcome that the school has 68 desktop computers mounted for the use of students at the schools' computer laboratory out of which 59 are functional with 9 not working. The finding also came out that two (2) students are er a computer while the teacher is with a laptop and a projector to teach and demonstrate some practical lessons to the concerned students. The laboratory was affirmed to have two wall air conditions which are functional and in good working conditionas at the time of researchers' visitation to the school.

Furthermore, it was found out that the school has two laboratories for practical; one for the home economics and the other for the technical department of the school. These 
Journal of Educational Research in Developing Areas (JEREDA

Vol. 2. Issue 2, Pp. 153-163, 2021

http://www.jeredajournal.com

E-mail: info@jeredajournal.com

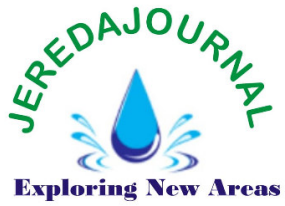

laboratories are furnished with tools and cooking utensils that students used. Apart from these two laboratories, the school is said to have a big long hall as its science laboratory which is furnished with apparatus for practical by students. What this finding implies is that with the availability of well-furnished computer/ laboratory in our school system there will be a significant improvement in the teaching and learning process and therefore will encourage pupils' attendance in school.

Hypothesis three, which stated that there is no significant relationship between good furniture/ fittings facility and pupils' attendance in public primary schools in Kwara State was rejected. Hence, there was significant relationship between good furniture/fittings facility and pupils' attendance in public primary schools in Kwara State. This therefore, implies that pupils' attendance in public primary schools is motivated by the availability of good furniture such as benches and lockers, chairs and tables; and also fittings like electrical with fans and other facilities. Valikhani et. al. (2015) in their study supported the finding of this study by identifying the major roles of school furniture which is designing and purchasing of furniture for school. They further identified two major functions of chairs and desks in supporting children while attending to teacher and holding them when writingor drawing on the working surface. Thereafter, the standards of this furniture are paramount for consideration. Their study revealed further that school furniture should be pleasing (good looking), durable, comfortable, inexpensive, conform to national performance quality standards, easily maintained and simply repaired, mobile and portable (light weight), functionally adjustable, provide safety, provided dynamic and active sitting during different lessons and provide more freedom of movements for the legs.

In view of this, their study concluded that schools furniture with the identified features of goodness for writing position, sitting position, functionally adjustable (to reduce back pain and

prevent musculoskeletal disorders) and on-task behavior will promote children's health and well-being at primary schools in Malaysia. Therefore, good furniture with some notable characteristics will motivate and encourage pupils' attendance in primary schools.

Also, Mcgowen (2007) in his study on the impact of school facilities on student achievement, attendance, behaviour, completion rate and teacher turnover rate in selected Texas High School, a regression model of the Total Learning Environment Assessment (TLEA) seven subsections which answered the question raised as to what extent do school facilities impact student attendance at selected Texas High Schools was not statistically significant forstudent attendance. The ANOVA calculation showed a significance level of only 0.291, which fall below the acceptable 0.05 level. The results of this study may have varieddue to the small sample size and the compactness of the dataassociated with campus attendance rates. Attendance rates for the participant schools only varied from 90.5 to 96.8 percent, with a standard deviation of 1.29 .

\section{CONCLUSION}

Based on the findings of the study, it was concluded that the learning environment and pupils' attendance in public primary schools in Kwara State are well correlated. That is, the availability and adequate supply of good furniture/fittings facilities, well ventilated classrooms and furnished computer studio/ laboratory have a positive significant relationship to pupils' attendance in public primary schools in Kwara State. This however, implies that adequate supply of furniture/fittings, ventilated classrooms and well-furnished computer studio/laboratory would motivate pupils' attendance in public schools in Kwara State.

\section{RECOMMENDATIONS}

According to the findings of the study and the conclusion reached, the following recommendations were made: 
Journal of Educational Research in Developing Areas (JEREDA

Vol. 2. Issue 2, Pp. 153-163, 2021

http://www.jeredajournal.com

E-mail: info@jeredajournal.com

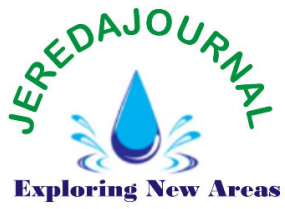

1. Government in the state through the SUBEB should ensure that more classrooms with wider space are built for the public primary schools to accommodate more pupils and to also encourage the pupils' attendance in the schools.

2. Kwara State Government should also ensure that provision should be made for acquisition of more electrical fittings such as fans to encourage pupils' attendance in public primary schools in Kwara State.

3. More teaching and learning facilities should be provided in public primary schools in Kwara State to encourage and motivate pupils' attendance in schools in the State.

4. Provision should be made by the State Government through SUBEB for computer laboratory with relevant play kits/ software in order to encourage pupils' attendance in public primary school in Kwara State.

Conflict of Interest: The authors did not declare any conflict of interest.

\section{Authors' Bionote}

Shuaib, Folorunsho Muhammed: The researcher is a staff of the Kwara State University, Molete. He is currently a Ph.D student in the Educational Administration and Planning section of the department of Educational Foundation and Curriculum, Ahmadu Bello University, Zaria. He is a Full Member of Chartered Institute of Public Diplomacy and Management (CIPDM). $\mathrm{He}$ is also a member of the Nigerian Association for Educational Administration and Planning (NAEAP), registration No: 01613 . He is interested in research on educational administration and planning.

Rilwan, Abayomi Ajayi: This researcher is a staff of Modibbo Adama University, Yola, Adamawa state in the Dept of Vocational Education. He holds Master Degree in Educational Management from University of Ilorin, Ilorin, Nigeria.

Oladimeji, Olayiwola: A Ph.D student at the Department of Educational Management, University of Ilorin, Nigeria. He is a research student on educational planning.

Authorship and Level of
Contributions
Shuaib, Folorunsho developed the introduction, statement of the problem, purpose of the study, research questions, formulation of hypotheses and the methodology adopted and development of instrument used for the study, administration and validation of the instrument. Also, the analysis of the instrument in addition to the interpretation of the result was done. Finally came up with the conclusion and recommendations to the study.

Rilwan, Abayomi Ajayi contributed to the development of the instrument used for the study. Necessary observations and corrections were made in the methodology adopted for the study. He came up with some useful points for recommendations to the study. $\mathrm{He}$ handled the administration of the instrument for pilot study to ascertain the reliability of the instrument.

Oladimeji, Olayiwola came up with the topic of the study. He also contributed to the development of the instrument used for the study and handled the administration of instrument to some part of the schools in Kwara South senatorial district. He did the validation of the instrument through an expert at the department of Educational Management, University of Ilorin.

\section{Disclaimer Statement}

We hereby declare that this paper is a new developed research work. This study has not been submitted to any other authority or institutions. All texts quoted directly or paraphrased have been indicated by in-text citations and full bibliographic details are given in the references. 
Journal of Educational Research in Developing Areas (JEREDA

Vol. 2. Issue 2, Pp. 153-163, 2021

http://www.jeredajournal.com

E-mail: info@jeredajournal.com

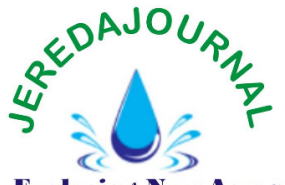

\section{References}

Aiwuyo, A., \& Osakue, S. O. (2019). An assessment of the learning environment of early childhood and development education in public schools in Esan West Local Government area of Edo state, Nigeria.International Journal of Sociology, 3(1), 15-19.

Dorman, J. P., Aldridge J. M., \& Fraser, B. J. (2006). Using students' assessment of classroom environment to develop a typology of secondary school classroom. International Journal, 7(7), 906915.

Ezike, B. U. (2018). Classroom environment and Academic interest as correlates of achievement in Senior Secondary School Chemistry in Ibadan South West Local Government Area, Oyo State, Nigeria. Global Journal of Educational Research, 17, 61-71.

Glossary of Educational Reform (2013: $3^{\text {rd }}$ November, 2020). Learning Environment. www.edglossary.org.

Kwara State Ministry of Education, Science and Technology (2010). Annual School Census Report, 2009 - 2010, August, 2010.

Federal Ministry of Education (2014). National policy on education NERDC.

Mcgowen, R. S. (2007). The impact of school facilities on student achievement, attendance, behaviour, completion rate and teacher turnover rate in selected Texas High Schools. Educational
Administration, 47(3), 1-151.

Oluremi, O. F. (2012). Creating a friendly school learning environment for Nigerian children. Learning Environment for Nigerian Children, $8(8), 138-147$.

Otchere, S. N., College, M., \& Asene, A. (2019). Examining the relationship between school facilities and the learning environment: A case study of oda senior high school. Journal of Education and Practice, 10(26), 2139. https://doi.org/10.7176/jep/1026-02.

Powell, S. R., \& Driver, M. K. (2013). Working with exceptional students: An introduction to special education. Bridge Point Education, Inc.

Raccoon, G. (2018: 20 ${ }^{\text {th }}$ June, 2021).What makes good learning environment:

https://raccoongang.com/blog/what -makes-good-learningenvironment/)

Teddlie, C., \& Reynolds, D. (2000). The international handbook of school effectiveness research. Falmer Press.

Terry, H. (2021: 25 ${ }^{\text {th }}$ June). The characteristics of a highly effective learning environment: https://www.teachthought.com

Valikhani, M., Ibrahim, R. \& Dolah, M. S. (2015). The influences of furniture on children's health and well-being at primary school. Journal Technologi, 78(5), 246-252. 